\title{
The Effect of Altruism Behavior, Peer Support and Leader Support on Employee Voice ${ }^{1}$
}

\author{
Celal ERKUBILAY (D) a Faruk Kerem ŞENTÜRK (iD b \\ a Bolu Forest Regional Directorate, Bolu, Turkey. cerkubilay@hotmail.com \\ b Duzce University, Faculty of Business, Düzce, Turkey. keremsenturk@duzce.edu.tr
}

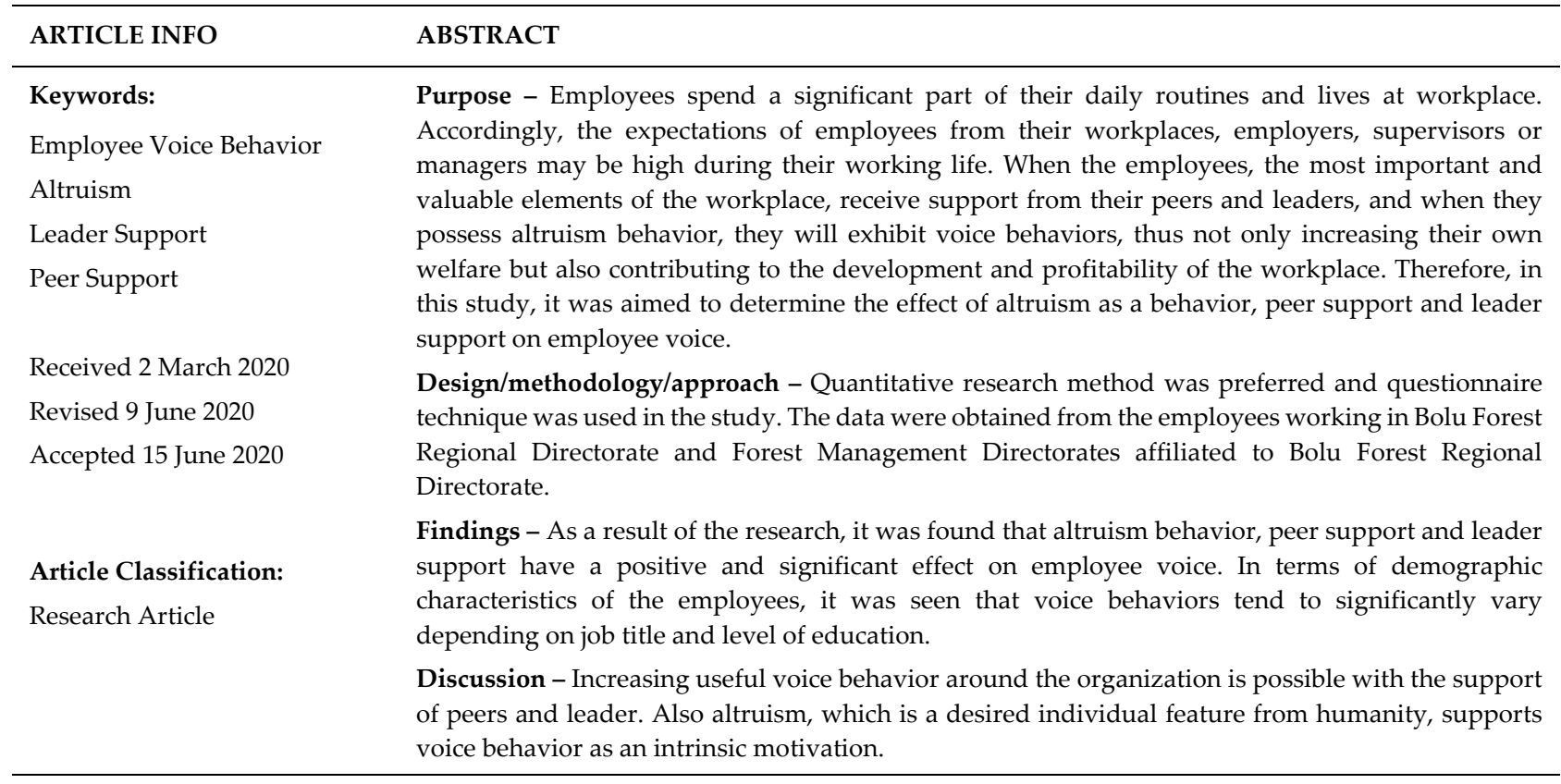

\section{Introduction}

Individuals spend a notable part of their day and the most valuable time of their lives in business life. Throughout the business life, employees tend to have expectations from their workplaces, employers, supervisors or managers, as well as employers, supervisors and managers. Rather than criticizing the management and functioning of the employee in the organization, the importance of voice behavior defined as positive and constructive behavior for the development, welfare and productivity of the organization (Van Dyne \& Le Pine, 1998) stands out. Despite the fact that voice behavior is defined as excellent with mutual merits for both employee and organization, it cannot be said that every employee exhibits voice behavior patterns. There are many reasons that encourage the employee voice behavior, as well as many factors that keep the employee silent.

The altruism behavior, used to express unrequited and unhindered solidarity, is also of big significance in business life. The fact that employees provide financial and moral support to each other in the workplace environment where they spend a significant part of our daily life can increase the solidarity between them and provide an environment in which they can exhibit voice behavior. The time periods that employees spend at workplace working can be expressed as the periods when they need solidarity the most. Employees often have to spend more time with their colleagues than they do with their families, relatives, and close friends. The fact that the employees help each other at their work and attempt to encourage each other can be considered as an indicator of harmony and voice behavior in the work environment. The executives exhibiting compliance with employees are as important as getting support from colleagues. The basic expectation of the employees from their managers is to trust their managers, to reach them when necessary, to understand the management in the event of illness and to have good communication model between the employee and the manager

${ }^{1}$ This study was produced from Celal ERKUBiLAY's master thesis. 
(Zeytinoğlu et al., 2001). As long as the managers and supervisors support their employees in this way, it is thought that positive emotions will emerge instead of negative emotions among the employees and employees then will tend to exhibit voice behaviors. In this study, it is aimed to determine the effect of altruism behavior, peer support and leader support on employee voice by taking into consideration the fact that voice behavior promotes the welfare, and peace experienced by the employee besides the benefits it provides to the development, welfare and profitability of the workplace.

\section{Literature Review}

\subsection{Altruism Behavior}

This concept is named differently in different languages which are "altruism " in English," "diğerkamlik" in Persian, "Issar" in Arabic and in the Holy Quran referring to the zenith of generosity, "özgecilik" in Turkish referring to doing the best for the good of others was derived Latin root "Alter" meaning "Other". In the 1830s, Auguste Comte was the first person to use this expression as a general term in the meaning of "caring for others" (Green, 2005). In the literature, altruism is defined as caring for the other, in other words, an act of helping each other. The personality traits equipping the individual with a tendency to help others in various settings is described as altruistic behavior (Budak, 2000) and the person who sacrifices himself for the good of others is called altruist (Littauer, 2002).

While altruism behavior was initially included among the research topics of religion and philosophy fields, it was started to be investigated by theoreticians and researchers in the field of psychology as well once philosophy turned into a scientific discipline (Yöntem \& İlhan, 2013). Since it emerged as a field of research, this behavior in question has confronted the researchers arguing that altruism behavior exists and that it is a part of human nature, and also those of the opinion that altruism behavior cannot actually exist. The vast majority of researchers focus their research on a view that altruism behavior is actually impossible and stems from the egoist motivations of human nature (Budd, 1956; Act. Mlcak \& Zaskodna, 2008). Philosophers who claim that man is existentially good defined him as socially collaborative, moral, sympathetic, and altruistic. Socrates, Aristotle, Jean Jacques Rousseau and Abraham Maslow are among those who support this point of view. In contrast, Sophists, St. Petersburg. Poul Machiavelli, Hobbes consider human nature as non-social, individualistic, selfish and aggressive (Duru, 2002).

As the altruism behavior is also a research subject of different sciences, different theoretical foundations have been made for it. For example; it is studied within the scope of psychoanalytic theory, social learning theory, moral development theory, social exchange theory, empathy-altruism theory and biology-evolution theory (Keleş, 2018). Some of these are mentioned above. In the following section, positive social (prosocial) behavior theory, on which we have built the theoretical basis of our study, is explained.

\subsection{Prosocial Behavior}

Prosocial behavior and positive social behavior are used in the same sense in the literature (Akbaba, 1994). Prosocial behaviors are behaviors intended to help or provide benefit to another person or group. These (acts or actions) are voluntary behaviors, they are not performed with coercion. While prosocial behaviors aim at positive outcomes for the good of others, individuals may also be willing to help someone for selfish reasons (such as expecting reward or something in return) (Eisenberg \& Mussen, 1989). In this context, it can be said that prosocial behavior covers such elements as empathy, sympathy, compassion, interest, consolation, helping each other, sharing, cooperating, volunteering and donating (Trommsdorff et al., 2007). Therefore, prosocial behaviors have beneficial features that are performed without necessity as well (Karadağ \& Mutafçlar, 2009).

It cannot be distinguished whether the intention of individuals who exhibit prosocial behavior is to provide unrequited help or to gain material or moral benefits (Kumru et al., 2004). Prosocial behaviors can be defined as behaviors that are beneficial to society. It is stated that empathic concern, moral reasoning, compliance and ability to assume the perspective of others may be related to prosocial or altruistic personality (Dovidio \& Penner, 2001). Prosocial behaviors may not always be altruism behaviors, even if they are to benefit others (Yildiz et al., 2012). As it can be understood from here, the similarity between prosocial behavior and altruism behavior is to help or provide benefit to others. As for the difference, while altruism behaviors are performed voluntarily and unrequitedly, prosocial behaviors can be performed by acting selfish or expecting something 
in return.

Although altruism behavior is a prosocial behavior, not every prosocial behavior is an example of altruism behavior in essence. This is better understood once looked at definitions of altruism behavior and classification of prosocial behavior. The most important difference that distinguishes altruism from other prosocial behaviors is the drive of motivation. On the basis of altruism behavior lies the fact that the person who performs the behavior (except for the feeling of fulfilling conscientious responsibility) does not expect any reward. In other words, even though it is prosocial behavior, helping someone with the idea that they will provide you with an interest is not altruism behavior (Freedman et al., 1993).

Altruism is a motivation aimed towards increasing the welfare of another person and is in complete contrast to egoism which is the motivation to increase one's own welfare (Batson \& Powell, 2003). Voice behavior also includes motivation to help the organization, society or the individual and it is stated that it is a collaborative behavior based on altruism (Van Dyne et al., 2003). Altruistic behavior is based on voluntarism, while complaint behavior for a mistake is expected. However, the result of both lies in the drive to provide benefit to others rather than expecting an external reward. Therefore, the behavior of expressing a problem in the workplace can be based on the thinking of the individual's business or colleagues rather than the individual himself/herself (Goldman \& Fordyce, 1983). In short, individuals with a high tendency to exhibit altruism are expected to share their ideas and criticisms that enhance the welfare of the society or business in which they work. The hypothesis obtained in accordance with the literature findings is as follows:

\section{H1: Employees' tendency towards altruism positively affects employee voice.}

\subsection{Peer Support and Leader Support}

In order to better understand the concepts of peer support and leader support, the concept of Social Support which is thought to be the basis of the subjects was prioritized.

\subsubsection{Social Support}

Support is expressed as the perceived flow of various contributions, appreciation, emotions and information from different sources (Parasuraman et al., 1992). Boldwin (1967) defines social support as the psychological support that an individual receives from his or her environment and states that the theoretical basis of social support is based on Kurt Lewin's Field Theory and Behavior Description. According to Field Theory, behaviors of individuals are a function of their living spaces. The living space is the individual and the physical and psychological environment perceived by the individual. The concept of social support is a phenomenon within this psychological environment (Semerci, 2016).

The support that individuals receive from their spouses, families, children, relatives, friends, colleagues or managers is called social support (Tuğsal, 2017). Stokes and Levin (1986) stated that social support means the presence of people in their environment whom they can trust and who will care for them. In another definition, Çakır and Palabıyıkoğlu (1997) described social support as an aid provided to the individual in general by the people around him.

Benefiting from social support resources is closely related to physical and mental health. It is stated that physical and psychological problems may be experienced when there is no social support or inadequate (Holahan \& Moos, 1982).The setting of our business life consists of colleagues, leaders or managers we name as supervisors or executives, customers and suppliers. In the business environment, employees most often deal with colleagues and leaders and managers. Accordingly, in the next section of our research, briefly the organizational support issue and then the independent variables of the research, "Peer Support" and "Leader Support" are provided.

\subsubsection{Organizational Support}

Working individuals spend most of their daily lives at their workplaces. For this reason, a supportive work environment is very important in terms of employee's personal happiness. Employees do not expect only money or concrete success from their work (Erdoğan, 1999). Eisenberger et al. (1986) defined organizational support as the belief in which employees hold the belief that the organization values their efforts and cares about their well-being. Özdevecioğlu (2013) stated that perceived organizational support is the fact that employees feel safe and know that there is an organization behind them. 


\section{Erkubilay - F. K. Şentürk 12/2 (2020) 1820-1833}

Organizational support depends on what the degree of positive attitude of the organization to its employees is (Eisenberger et al., 1986). Employees receiving support from the organization further increase their efforts for the organization to achieve its objectives in order to reward this support (Aselage \& Eisenberger, 2003). This is theoretically based on the principle of reciprocity in the relationship of social exchange. Employees believe that their efforts they show for the the organization to achieve its goals will be recognized and rewarded (Allen \& Brady, 1997). Maslach and Leiter (1997) state that employees work best for the organization when they share happiness, comfort, humor and appreciation with people they respect and love in the workplace. The positive conditions an organization provides to its employees voluntarily are more effective on the perception of organizational support when the organization does not have any obligations (Eisenberger et al., 1997). In addition, it is suggested that stress level diminishes as employees' perception of organizational support increases (Cropanzano et al., 1997). Hence, it is argued that a supportive work environment reduces stress and its negative effects thereof (Schaubroeck et al., 1989).

\subsubsection{Peer Support}

This concept covers counseling of colleagues about the job (Ensher, et al., 2001) and friendship relationships in its scope (Morgeson \& Humphrey, 2006) but by definition, it means sharing experiences and expertise of employees with each other when needed and helping each other in their duties and encourage and provide support to each other (Zhou \& George, 2001). Colleagues can turn the work into a more enjoyable place by helping each other, making suggestions, developing suggestions, relaxing and supporting each other (Bishop \& Scott, 1997). In situations where the work feels very repetitive and annoying, positive relationships established with colleagues may be one of the most important means of not alienating from work (Çoruh, 2001). It can be expected that individuals who are in positive relationships and communicating with their colleagues with whom they have to constantly interact in the work environment, will achieve more satisfaction (Bergbom \& Kinnuen, 2014).

Bowen and Blackmon (2003) emphasize that employees exhibit voice behavior when they receive support from their colleagues and tend to remain silent when they do not. Aselage and Eisenberger (2003) state that the efforts exhibited by employees who receive support from their colleagues will increase in order for the organization to reach its goals in an attempt to reward the support they receive. Also, Derin (2017) stated that increasing the level of trust among employees within the organization will end up with psychological comfort and employee voice, and that it will indirectly increase the performance of the organization. The hypothesis obtained in accordance with the literature findings is as follows:

\section{H2: Peer support perceived by the employees positively affects employee voice.}

\subsubsection{Leader Support}

Employees in many businesses communicate more with their managers or supervisors than they do with the entire organization. For this reason, leaders, managers and supervisors play an important role in shaping employees' perceptions of organizational support (Maertz et al., 2007). At the same time, managers and leaders are highly effective in allowing the employee to reach work satisfaction. Managers respected and valued by the organization may have a major impact on organizational support, perceived by being identified with the organization (Maertz \& Griffeth, 2004).

Leader support consists of the expectations of employees to be cared and contributed by their managers and superiors (Kottke \& Sharafinski, 1988). For working individuals, their being supported and encouraged by their managers is the degree where the interest shown to them is perceived (Burke et al., 1992).A supportive manager plays a mitigating role in cases where perceived organizational support is low, hiding the deficiencies of the organization and preventing the increase of voluntary resignations from the work. When looked from the negative perspective, managers can translate the employee's perception of the organization's resources and support into their own interests (Eisenberger et al., 2002).

Perceived leader support leads the perception of organizational support, but employees do not regard the support they receive from the organization equal to leader support (Eisenberger et al., 2002), because managers provide both instrumental and emotional support, and even if there is no demand, they tend more to offer support. Therefore, it is expected that their ability and experience in providing support and assistance should be greater than that provided by their colleagues (Ng \& Sorensen, 2008). 


\section{Erkubilay - F. K. Şentürk 12/2 (2020) 1820-1833}

Walumbwa and Schaubrouck (2009) state that leadership behaviors in harmony with employees and high level of responsibility can positively increase employee voice. Gao et al. (2011) stated that employee voice behavior would also increase in the organizations in which the trust in the leader is increased, the participation of the decisions is supported and the leader's knowledge sharing is high. Detert and Burris (2007) state that employees exhibit a higher rate of voice behavior in environments where they feel psychologically safe within the organization. The hypothesis obtained in accordance with the literature findings is as follows:

H3: Leadership support perceived by employees positively affects employee voice.

\subsection{Employee Voice}

The concept of voice stems from the idea of expressing some dissatisfaction or negativity about work in order to increase the welfare of the employees themselves or their organizations (Hirschman, 1970). The concept of voice, first coined by Hirschman (1970), is one of the triple theories of Voice", "Loyalty "and "Exit" (EVL). Based on Hirschman's study, Rusbult et al. (1982) added a fourth dimension, called "Neglect", in their study tittled "Reactions to Dissatisfaction in Romantic Relations" as a reaction to dissatisfaction. Farrell (1983) defined "EVLN "theory as a useful conceptual framework that can be used in analyzing employee dissatisfaction.

Rather than just directing a criticism towards management and operations within the organization, employee voice behavior stands for exhibiting positive and constructive behavior for the development, welfare and efficiency of the organization. It is also to provide innovative recommendations for changing stereotypes even if the opinions of other employees are not the same (Van Dyne \& Le Pine, 1998). According to another definition, voice behavior is a voluntary action displayed taking into account the possibility of putting the organization into a struggle for change in order to activate and develop the perceived authority (Detert \& Burris, 2007).

Table 1: Types of Employee Voice

\begin{tabular}{l|l}
\hline $\begin{array}{l}\text { Types of Employee } \\
\text { Voice }\end{array}$ & \multicolumn{1}{c}{ Definitions } \\
\hline Speaking Up & $\begin{array}{l}\text { Act of speaking up can occur when employees are faced with a problem } \\
\text { individually, notifying potential problems to their managers and supervisors, or } \\
\text { presenting their ideas and suggestions to reduce organizational costs to their } \\
\text { managers (Pekdemir et al., 2013). }\end{array}$ \\
\hline Imposing & $\begin{array}{l}\text { Imposing a topic is expressed as attempts to draw the organization's attention to } \\
\text { modern techniques and methods for the performance of the organization (Ashford } \\
\text { et al., 1998). This concept is a behavior that is acted towards openly breaking the } \\
\text { silence that exists in the organization and also towards voice (Çakicl, 2007). }\end{array}$ \\
\hline Whistleblowing & $\begin{array}{l}\text { Whistleblowing is to convey the issues to the individuals who can correct the issues } \\
\text { about the unlawful, unethical and unethical issues performed within the } \\
\text { organization and which do not coincide with the rules determined by the } \\
\text { organization (Miceli \& Near, 1985). }\end{array}$ \\
\hline $\begin{array}{l}\text { Taking } \\
\text { Responsibility }\end{array}$ & $\begin{array}{l}\text { Taking responsibility is a voluntary behavior made in order to make a change in } \\
\text { the operation of the business. Taking responsibility is regarded as an informal } \\
\text { leadership style that involves voluntary, constructive initiatives to realize } \\
\text { functional changes in how organizational activities are performed. The act of taking } \\
\text { responsibility involves change-oriented and attempts to change the status quo } \\
\text { (Premeaux \& Bedeian, 2003). }\end{array}$ \\
\hline & $\begin{array}{l}\text { The principled organizational opposition is based on violating the existing rules } \\
\text { and practices of the business and is aimed at making it give up existing policies } \\
\text { and practices. The principled organizational opposition can be encountered in }\end{array}$ \\
\hline
\end{tabular}




\begin{tabular}{l|l}
\hline Opposition & $\begin{array}{l}\text { many forms, from constructive criticism to strike and even to take preventive } \\
\text { actions (Graham, 1986). }\end{array}$ \\
\hline $\begin{array}{l}\text { Influencing the } \\
\text { Superiors }\end{array}$ & $\begin{array}{l}\text { The behavior of influencing superiors is defined as an attempt exhibited by } \\
\text { considered positive for both the person trying to influence and the business. It also } \\
\text { means determining the methods and techniques to facilitate the achievement of the } \\
\text { specified objectives of the organization he/she is a part of and in this direction, } \\
\text { acting carefully and diligently in order for the objectives to be clearer and more } \\
\text { pronounced. (Çakıc1, 2007). }\end{array}$ \\
\hline
\end{tabular}

As stated in the table, voice behavior can emerge for different reasons and purposes. However, according to Van Dyne et al. (2003) examining employee silence in the context of voice, it is stated that there are three different voice behaviors which are defensive voice, voice for the good of organization and perceived voice. In this sense, defensive voice is he motivation to defense himself/herself. The essential motive for defensive voice is that an individual acts as a voice to protect himself/herself due to his/her fear of his superior or management. Voice for the good of the organization not remaining silent for the problems encountered in the organization or in the face of a negative situation believing that it will be for the interests of the organization (Çakıc1, 2007). Perceived voice is the verbal expression of emotions, thoughts and ideas on issues related to the field of duty, rather than transferring them directly according to perceived thoughts within the organization (Van Dyne et al., 2003).

\section{Method}

In this study, we preferred quantitative research method. While doing so, what we aimed was to produce the information explaining generalizable cause-effect relationships. In the research, relational screening model was used. Relational screening method is defined as a research model aiming to determine the existence or degree of the change between two or more variables (Karasar, 2002).

\subsection{Study Population and Sample}

The population of the research was made up of all civil servants and workers, including the managers working in the Bolu and Düzce provinces in Bolu Regional Forest Directorate. As it was not possible to reach the whole universe, sampling method was used. To calculate the number of samples "n = N.t².p.q / $d^{2}$. (N-1) $+t^{2} . p \cdot q^{\prime \prime}$ formula was applied (Karagöz, 2014) and the number required to be reached was determined as 283 . A total of 361 questionnaires were collected, while 15 questionnaires were removed due to different reasons. The research was carried out over 346 questionnaires available.

\subsection{Data Collection Tools}

\subsubsection{Altruism Scale}

The "Altruism Scale", used to measure the level of exhibited altruism behaviors of employees, was developed by Rushton et al. (1981). The scale consists of 20 expressions. As independent variables, the research model consists of leader support, peer support and altruism behavior, whereas employee voice as the dependent variable. Cronbach alpha internal consistency coefficients obtained from five different applications during the scale development study ranged from .78 to .87 (Rushton et al., 1981). Turkish adaptation of the scale was carried out by Tekeş and Hasta (2015). The scale, which was adapted to Turkish, showed a two-factor structure called help and donation. Cronbach Alpha internal consistency coefficients calculated for the sub-dimensions were .81 and .70 , respectively. The reliability coefficient of the scale was found to be .74 and test-retest reliability was found as .83 (Tekeş \& Hasta, 2015). According to the exploratory factor analyzes conducted within the scope of the research, it was determined that KMO (.883) and Bartlett Test (.000) results were appropriate for factor analysis and the remaining 19 expressions had a factor loadings ranging from .71 to .44 after removing one 1 expression (13th expression) from the scale, and $34 \%$ of the total variance was explained under a single factor. The reliability coefficient was found to be at the level of .89 .

\subsubsection{Peer Support Scale}

In order to measure the perceived levels of employee peer support, a four-item peer support scale developed 


\section{Erkubilay - F. K. Şentürk 12/2 (2020) 1820-1833}

by Zeytinoğlu et al. (2001) was used. There was no reverse coded item on the scale which was used as a single factor in its original form. While Cronbach's alpha coefficients in the original samples ranged between .75 and .87 , Şentürk and Tekin (2015), who adapted the scale to Turkish, demonstrated the reliability of the scale at the level of .78. According to the exploratory factor analysis conducted within the scope of the research, it was found that KMO (.792) and Bartlett Test (.000) results appropriate for factor analysis, and factor loadings of the 4 expressions in the scale varied between .79 and .85 and also that $67 \%$ of the total variance was explained under a single factor. The reliability coefficient was found to be .83 .

\subsubsection{Leader Support Scale}

A scale consisting of five items called "Leader Support Scale" which was developed by Netemeyer et al. (1997) was used to measure the perceived leadership support of employees. There was no reverse coded item on the scale which was used as a single factor in its original form. The scale was translated into Turkish by Çelik and Turunç (2010) and as a result of the reliability analysis, the Cronbach alpha reliability coefficient of the scale was found to be .95 . As a result of the reliability analyzes conducted by Akkoç et al. (2012), the Cronbach alpha reliability coefficient was detected to be .92 . According to the exploratory factor analysis conducted within the scope of the research, we found that KMO (.900) and Bartlett Test (.000) results were appropriate for factor analysis, and factor loadings of the 5 expressions in the scale varied between .86 and .93 and that $80 \%$ of the total variance was explained under a single factor. The reliability coefficient was found to be at the level of .93 .

\subsubsection{The Employee Voice Scale}

A six-item scale called "The Employee Voice Scale", which was developed by Van Dyne and LePine (1998), was used to measure the voice behavior levels of the employees. The validity and reliability study of the scale was conducted by Arslan and Yener (2016) and adapted to Turkish. Both the original and Turkish scale forms were one-dimensional and the Cronbach's alpha reliability coefficient was found to be .76 . The internal consistency value of the original scale was .82 (Arslan \& Yener, 2016). According to the exploratory factor analyzes conducted within the scope of the research, it was determined that KMO (.901) and Bartlett Test (.000) results were appropriate for factor analysis, and factor loadings of the 6 expressions in the scale varied between .81 and .88 and also that $71 \%$ of the total variance was explained under a single factor. The reliability coefficient was found to be at the level of .92 .

\subsection{Research Model}

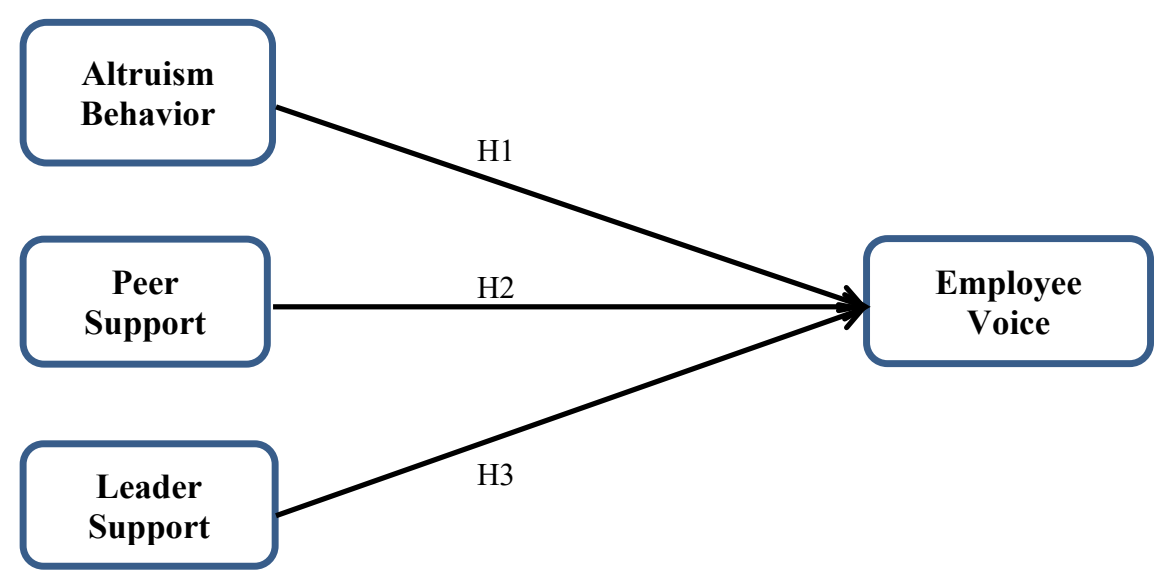

The hypotheses formed within the scope of literature review are indicated in the model above. . The hypotheses generated in this sense are as follows:

- H1: Employees' tendency towards altruism positively affects employee voice.

- H2: Peer support perceived by employees positively affects employee voice.

- H3: Leader support perceived by employee positively affects employee voice.

\section{Results}




\section{Erkubilay - F. K. Şentürk 12/2 (2020) 1820-1833}

In this part of the study, the regression analysis findings carried out to test the hypotheses and interactions between the dependent variable and the employee voice which is the dependent variable of the research, and will be addressed.

Table 2: Regression Analysis of Altruism Behavior, Colleague Support, Leader Support and Employee Voices

\begin{tabular}{|c|c|c|c|c|c|c|c|c|c|}
\hline Variables & B & $\begin{array}{l}\text { Std. } \\
\text { Error }\end{array}$ & $\beta$ & $\mathbf{t}$ & $\mathbf{p}$ & ت & ت. & ○ं & VIF \\
\hline (Constant) & ,645 & ,207 & - & 3,111 & ,002 & - & - & - & - \\
\hline Altruism Behavior & ,172 & ,057 & ,128 & 3,026 & ,003 & ,409 & ,161 & 809 & 1,235 \\
\hline Peer Support & ,466 & ,048 & ,463 & 9,631 & ,000 & ,661 & ,462 & ,629 & 1,590 \\
\hline Leader Support & ,221 & ,040 &, 257 & 5,488 & ,000 &, 565 & ,284 & ,661 & 1,513 \\
\hline \multicolumn{10}{|c|}{ Dependent Variable: Employee Voice } \\
\hline R: , 710 & $\mathbf{R}^{2}:, 504$ & \multicolumn{3}{|c|}{ F: 115,635} & \multicolumn{2}{|c|}{ p:, 000} & \multicolumn{3}{|c|}{ Durbin-Watson: 1,911 } \\
\hline
\end{tabular}

When the paired correlation scores were evaluated, correlation results were obtained between peer support ( $\mathrm{r}$ $=, 661)$, leader support $(\mathrm{r}=, 565)$, altruism behavior $(\mathrm{r}=, 409)$ and dependent variable. Accordingly, it can be seen that there is a positive and moderate relationship between independent variables and employee voice .When the partial correlation scores were evaluated, some scores were obtained between peer support $(\mathrm{r}=$ ,462), leader support $(\mathrm{r}=, 284)$, altruism behavior $(\mathrm{r}=, 161)$ and dependent variable. Accordingly, it can be said that the independent variables have a positive but low level of partial relationships on employee voice.

When the VIF values are examined, it is understood that the variables do not get a value higher than 10 and when the fact that the tolerance values are not less than 0,20 is considered, there is no multicollinearity between independent variables. In addition, Durbin Watson statistic, which is required to be between 0-4, investigates whether there is any correlation between error terms. In the study, Durbin Watson value was found to be 1.911 and no problematic relationship was detected between error terms .

The level of explanation for dependent variable $\left(0 \leq R^{2} \geq 1\right)$ of the independent variables is statistically significant ( $\mathrm{R}^{2}$ : ,504, F: 115.635 , p: 0.000). According to this result, independent variables (peer support, leader support and altruism behavior) can explain $50.4 \%$ of the change in the dependent variable (employee voice). When the standardized regression coefficients $(\beta)$ are analyzed, the relative importance order of the variables on employee voice can be listed as peer support, leader support and altruism behavior.

When the t-test results regarding the significance of regression coefficients are analyzed, it can be seen that perception of peer support, perception of leader support and altruism behavior has a significant effect on employee voice. According to this, the below mentioned hypotheses are accepted:

H1: Employees' altruism tendency positively affects employee voice.

H2: Peer support perceived by employees has a positive effect on employee voice.

H3: Leadership support perceived by employees positively affects employee voice.

\section{Discussion and Recommendations}

In the study, it was seen that altruism behavior, peer support and leader support has a positive and significant effect on employee voice. In other words, employees with a high level of altruism may exhibit a high level of 


\section{Erkubilay - F. K. Şentürk 12/2 (2020) 1820-1833}

voice behaviors when they receive support from colleagues and leaders. We have also seen that similar results have been obtained in the studies with similar characteristics as ours conducted in the literature about the factors affecting employee voice in recent years. However, since the studies in the literature do not have exactly the same patterns as this study, it is considered that it would be more useful to examine the relationship between employee voice-leader support, employee voice - peer support and employee voice - altruism behavior separately.

Among the factors affecting the voice behavior, what is mentioned mostly is the effects of leadership attitudes and behaviors as well as leadership styles on the organizational voice of the employee (Detert \& Burris, 2007; Çelik, 2008; Walumbwa \& Schaubrouck, 2009; Yang et al., 2010; Gao et al., 2011; Hsiung, 2012; Thomas \& Feldman, 2013; Öztürk, 2014; Ünver, 2016; Bulut, 2016; Çiçek, 2016; Çetin \& Güven, 2017; Güven, 2017). Regarding the effect of the executive's attitudes and behaviors on employee voice behavior, Walumbwa and Schaubrouck (2009) stated that leadership behaviors which are compatible with employees and have high level of responsibility increase employee voices positively and also Gao et al. (2011) concluded that in organizations where there is increased confidence in the executer, support for the participation of decisions, and a leader with high knowledge sharing, voice behavior should also increase, while Çetin and Güven (2017) came to the conclusion that trust in the executives has an effect on the voice behavior of the employee and Thomas and Feldman (2013) found that the perceived preoccupation of the executives has a significant effect on employee voice, and Çelik (2008) found that psychological empowerment would have a significant effect on employee voice.

There are similar results in the literature regarding the effect of perceived support from colleague on employee voice yielding similar results that support from colleagues affects employee voice behavior (Aselage \& Eisenberger 2003; Bowen \& Blackmon 2003; Derin 2017). Some of these similarities are as follows: Bowen and Blackmon (2003) emphasize that employees exhibit voice behavior when they receive support from their colleagues but remain silent when they do not. Aselage and Eisenberger (2003) state that the efforts of the employees who receive support from their colleagues will increase in order for the organization to reach its goals in an attempt to reward this support. The fact that employees feel psychologically safe is closely related to their colleagues, and Detert and Burris (2007) state that employees exhibit a higher rate of voice behavior in environments where they feel psychologically safe within the organization. Derin (2017) stated that increasing the level of trust among the employees within the organization would lead to psychological comfort and employee voice, therefore, the level of employee voice would increase and the performance of the organization could indirectly increase.

No other study in the literature related to one of the results obtained in the study "the effect of altruism on employee voice" has been found, making this study a new gain for the literature. Performing the tasks assigned to them is among the liabilities of employees within the organization and is a part of their job. However, contributing to the solution of the problems encountered in the work process while performing the duties requires additional responsibility for the employee. Additional responsibility behavior is proactive and based on altruism. Van Dyne et al. (2003), one of the pioneers who brought the concept of employee voice into the literature, emphasizes that motivation to help the organization, society or the individual is involved in voice behavior and is a collaborative behavior based on altruistic foundations. Based on the definition of selfsacrificing and depriving (Budak, 2000) for the good of others in altruism behavior, the hypothesis that individuals with high tendency towards altruism will exhibit voice behavior by sharing their ideas and criticisms that could increase the welfare of the society or business in which they work has been put forward. The results of the study support this hypothesis. The suggestions put forward as a result of the study are handled in three categories as the ones aiming at employees, managers and researchers. When the historical process is examined, it is seen that altruism behavior is realized in different ways and the reintroduction of these and similar behaviors into business life as in Ahi community will increase the quality of the employees both in the group and in their relations with management, thus leading to an increase in parallel with the feelings of loyalty to the organization. It has become a common fact that information flow is of vital importance in the present age. In this context, it is essential that managers activate the communication networks to get their subordinates' ideas on the development of the organization and solving the problems. However, the change emphasized in today's business world and particularly in digital processes, subordinates' ideas and suggestions bear importance in terms of problem-free management of processes.

Finally, based on the results of the research, the need for the senior management to pay attention to the process 


\section{Erkubilay - F. K. Şentürk 12/2 (2020) 1820-1833}

of forming work groups (teams) in the working environment can be said to have already emerged. Rather than being considered as a risk for the business, employees' expressing their ideas and suggestions supporting each other are of importance in terms of identifying the points overlooked by the top management and eliminating the problematic ones.

\section{References}

Akbaba, S. (1994). Grupla Psikolojik Danışmanın Sosyal Psikolojik Bir Kavram Olan Özgecilik Üzerindeki Etkisi. Doktora Tezi, Atatürk Üniversitesi, Sosyal Bilimler Enstitüsü, Erzurum.

Akkoç, İ., Çalışkan, A. \& Turunç, Ö. (2012). Örgütlerde Gelişim Kültürü ve Algılanan Örgütsel Desteğin İş Tatmini ve İş Performansına Etkisi: Güvenin Aracılık Rolü. Celal Bayar Üniversitesi İ.İ.B.F. Yönetim ve Ekonomi Dergisi, 19 (1), 105-109.

Allen, M. W. \& Brady, R. M. (1997). Total Quality Management, Organizational Commitment, Perceived Organizational Support, and Intraorganizational Communication. Management Communication Quarterly, 10(3), 316-341.

Arslan, A. \& Yener, S. (2016). İşgören Sesliliği Ölçeğinin Türkçe 'ye Uyarlanması Çalışması. Yönetim ve Ekonomi Araştırmaları Dergisi, 14(1), 173-191.

Aselage, J. \& Eisenberger, R. (2003). Perceived Organizational Support And Psychological Contracts: A Theoretical İntegration. Journal Of Organizational Behavior. The International Journal Of Industrial, Occupational And Organizational Psychology And Behavior, 24(5), 491-509.

Ashford, S. J., Rothbard, N. P., Piderit, S. K. \& Dutton, J. E. (1998). Out on a limb: The role of context and impression management in selling gender-equity issues. Administrative Science Quarterly, 43, 23-57.

Batson, C. D. \& Powell, A. A. (2003). Altruism and Prosocial Behavior içinde Handbook of Psychology (Ed. Irving B. Weiner), John Wiley \& Sons Inc., Canada

Bergbom, B. \& Kinnunen, U. (2014). Immigrants and Host Nationals at Work: Associations of Co-Worker Relations with Employee Well-Being. International Journal of Intercultural Relations, 43(B), 165-176.

Bishop, J. W. \& Scott, D. K. (1997). How Commitment Affects Team Performance. HR Magazine, 42(2), 107-111.

Boldwin, L. A. (1967) Theories of Child Development. John Willey and Sons, Inc. New York.

Bowen, F. \& Blackmon, K. (2003). Spirals of silence: The dynamic effects of diversity on organizational voice. Journal of management Studies, 40(6), 1393-1417.

Budak, S. (2000). Psikoloji Sözlüğü. Bilim ve Sanat Yayınları: Ankara.

Budd, L. J. (1956). Altruism Arrives in America. American Quarterly. 8(1), 40- 52.

Bulut, H. (2016). Liderlik Tarzlarının Çalışan Sesliliğine Etkisi: Kamuda Bir Araştırma. Yüksek Lisans Tezi, Kara Harp Okulu Komutanlığı, Savunma Bilimleri Enstitüsü, Savunma Yönetimi Anabilim Dalı, Ankara.

Burke, M. J., Borucki, C. C. \& Hurley, A. E. (1992). Reconceptualizing Psychological Climate in A Retail Service Environment: A Multiple-Stakeholder Perspective. Journal of Applied Psychology, 77(5), 717-729.

Cropanzano, R., Howes, J. C., Grandey, A. A. \& Toth, P. (1997). The Relationship of Organizational Politics and Support to Work Behaviors, Attitudes and Stress. Journal of Organizational Behavior, 18(2), 159-180.

Çakıcı, A. (2007). Örgütlerde sessiz kalınan konular, sessizligin nedenleri ve algılanan sonuçları üzerine bir araştırma. Çukurova Üniversitesi Sosyal Bilimler Enstitüsü Dergisi, 17 (1) , 117-134.

Çakır, Y. \& Palabıyıkoğlu, R. (1997). Gençlerde Sosyal Destek-Çok Boyutlu Algılanan Sosyal Destek Ölçeğinin Güvenirlik ve Geçerlik Çalışması. Kriz Dergisi, 5(1), 15-24.

Çelik, L. M. (2008). Voice Behavior of Blue Collar Employees: The Mediating Role of Psychological Empowerment. Yüksek Lisans Tezi, Koç Üniversitesi, Sosyal Bilimler Enstitüsü, İstanbul.

Çelik, M. \& Turunç, Ö. (2010). Lider Desteğinin Çalışanların Iş-Aile Yaşam Çatışması ve Iş Performansına 


\section{Erkubilay - F. K. Şentürk 12/2 (2020) 1820-1833}

Etkisi: Savunma Sektöründe Bir Araştırma. Çukurova Üniversitesi Iktisadi ve Idari Bilimler Fakültesi Dergisi, 14(1), 19-41.

Çetin, C. \& Güven, Ç. (2017). Çalışanların yöneticilerine duydukları güvenin ses davranışına olan etkisi ve bir araştırma. Marmara Üniversitesi Öneri Dergisi, 12 (48), 141-152.

Çiçek, B. (2016). Değer merkezli liderliğin etik iklim ve çalışan sesi üzerindeki etkisi. Doktora Tezi, İnönü Üniversitesi, Sosyal Bilimler Enstitüsü, Malatya.

Çoruh, E. (2001). Hazır Giyim Sektöründe Çalışanların Iş Doyumlarının Incelenmesi. Yüksek Lisans Tezi, Gazi Üniversitesi, Sosyal Bilimler Enstitüsü, Ankara.

Derin, N. (2017). İşyerinde Kişiler Arası Güven ile İşgören Sesliliği Arasındaki İlişkide Psikolojik Rahatlı̆̆ın Aracılık Rolü. Yönetim Bilimleri Dergisi, 15(30), 51-68.

Detert, J. R., \& Burris, E. R. (2007). Leadership behavior and employee voice: Is the door really open?. Academy of Management journal, 50(4), 869-884.

Dovidio, J. F., \& Penner, L. A. (2001). Helping and Altruism. Blackwell Handbook Of Social Psychology: Interpersonal Processes, 162-195.

Duru, E. (2002). Öğretmen Adaylarında Kişi-Durum Yaklaşımı Bă̆lamında Yardım Etme Davranışı Ĕ̆ilimi Empati ve Düşünme Stilleri İlişkisi ve Bu Değişkenlerin Bazı Psikososyal Değişkenler Açısından İncelenmesi. Doktora Tezi. Dokuz Eylül Üniversitesi Sosyal Bilimler Enstitüsü, İzmir.

Einsenberger, R., Cummings, J., Aemeli, S. \& Lynch, P. (1997). Perceived Organizational Support, Discretionary Treatment, And Job Satisfaction. Journal of Applied Psychology, 82(5), 812-820.

Eisenberg, N. \& Mussen, P. H. (1989). The Roots of Prosocial Behavior in Children. Cambridge University Press.

Eisenberger, R., Huntington, R., Hutchison, S. \& Sowa, D. (1986). Perceived Organizational Support. Journal of Applied Psychology, 71(3), 500-507.

Eisenberger, R., Stinglhamber, F., Vandenberghe, C., Sucharski, I. L. \& Rhoades, L. (2002). Perceived Supervisor Support: Contributions to Perceived Organizational Support and Employee Retention. Journal of Applied Psychology, 87(3), 565-573.

Ensher, E. A., Thomas, C. \& Murphy, S. E. (2001). Comparison of Traditional, Step-Ahead, And Peer Mentoring On Protégés' Support, Satisfaction, And Perceptions of Career Success: A Social Exchange Perspective. Journal of Business and Psychology, 15(3), 419-438.

Erdoğan, İ . (1999). Işletme Yönetiminde Örgütsel Davranış. I.Ü. Işletme Fakültesi, Istanbul.

Farrell, D. (1983). Exit, voice, loyalty, and neglect as responses to job dissatisfaction: A multidimensional scaling study. Academy of Management Journal, 26, 596-607.

Freedman, J. L., Sears, D. O., \& Carlsmith, J. M. (1993). Sosyal Psikoloji. (Çev. A. Dönmez). İmge Kitabevi Yayınları: Ankara.

Gao, L., Janssen, O., \& Shi, K. (2011). Leader trust and employee voice: The moderating role of empowering leader behaviors. The Leadership Quarterly, 22(4), 787-798.

Goldman, M., \& Fordyce, J. (1983). Prosocial behavior as affected by eye contact, touch, and voice expression. The Journal of Social Psychology, 121(1), 125-129.

Graham, J. W. (1986). Principled organizational dissent: A theoretical essay. Research in Organizational Behavior, $8,1-52$.

Green, W. S. (2005). Introduction: Altruism and the Study of the Religion. Altruism In World Religions. Georgetown University Press, USA.

Güven, Ç. (2017). Algılanan Liderlik Tarzlarının Çalışan Sesine Etkisinde Örgütsel Güvenin Rolü ve Bir Araştırma. Yüksek Lisans Tezi Marmara Üniversitesi, Sosyal Bilimler Enstitüsü, İstanbul

Hirschman, A. O. (1970). Exit, Voice, and Loyalty: Responses to Decline in Firms, Organizations, snd States (Vol. 25). 
Harvard University Press: USA.

Holahan, C. J. \& Moos, R. H. (1982). Social Support and Adjustment: Predictive Benefits of Social Climate İndices. American Journal of Community Psychology, 10(4), 403-415.

Hsiung, H. (2012). Authentic Leadership and Employee Voice Behavior: A Multi-Level Psychological Process. Journal of Business Ethics, 107(3), 349-361.

Karadağ, E. \& Mutafçılar, I. (2009). İlk ve Orta Öğretim Öğretmenlerinin Özgecilik Düzeyleri Üzerine Bir Araştırma. Ondokuz Üniversitesi Eğitim Fakültesi Dergisi, 28, 75-92.

Karagöz, Y. (2014). SPSS 21.1 Uygulamalı Biyoistatistik. Nobel Akademik Yayınları: Ankara.

Karasar, N. (2002). Bilimsel Araştırma Yöntemi. 12. Baskı, Nobel Akademik Yayınları: Ankara.

Keleş, M. (2018). Çevreci Sivil Toplum Kuruluşlarında Çalışanların Sosyal Sorumluluk Ve Özgecilik Düzeylerinin İncelenmesi: Ankara Örneği. Doktora Tezi. Ankara Üniversitesi, Sosyal Bilimler Ensitüsü, Ankara.

Kottke, J. L. \& Sharafinski, C. E. (1988). Measuring Perceived Supervisory And Organizational Support. Educational And Psychological Measurement, 48(4), 1075-1079.

Kumru, A., Carlo, G. \& Edwards, C. P. (2004). Olumlu Sosyal Davranışların İlişkisel, Kültürel, Bilişsel ve Duyuşsal Bazı Değişkenlerle İlişkisi. Türk Psikoloji Dergisi, 19(54), 109-125.

Littauer, F. (2002). Kişiliğ̈inizi Tanıyın. (Çev. D. Dizman), Sistem Yayıncılık: İstanbul.

Maertz, C. P. \& Griffeth, R. W. (2004). Eight Motivational Forces And Voluntary Turnover: A Theoretical Synthesis With İmplications For Research. Journal of Management, 30(5), 667-683.

Maertz, C. P., Griffeth, R. W., Campbell, N. S. \& Allen, D. G. (2007). The Effects of Perceived Organizational Support and Perceived Supervisor Support on Employee Turnover. Journal of Organizational Behavior, 28(8), 1059-1075.

Maslach, C. \& Leiter, M. P. (1997). The truth about burnout: How organizations cause personal stress and what to do about it. John Wiley and Sons: San Francisco.

Miceli, M. P. \& Near, J. P. (1985). Characteristics of Organizational Climate and Perceived Wrongdoing Associated with WhistleBlowing Decisions. Personnel Psychology, 38(3), 525-544.

Mlcak, Z. \& Zaskodna, H. (2008). Altruistic Motivation, Empathy and Affiliation. An Analysis of Data Collected Amongst Undergraduate Social Work Students Contribution to Creation of Psychology Conceptual Curriculum. P.Tarabek, P. Záškodný, (Eds.), Educational And Didactic Communication (123-134).

Morgeson, F. P. \& Humphrey, S. E. (2006). The Work Design Questionnaire (WDQ): Developing and Validating A Comprehensive Measure for Assessing Job Design and the Nature of Work. Journal of Applied Psychology, 91(6), 1321-1339.

Netemeyer, R. G., Boles, J. S., Mckee, D. O., \& Mcmurrian, R. (1997). An Investigation Into The Antecedents Of Organizational Citizenship Behaviors In A Personal Selling Context. The Journal of Marketing, 61 (3), 85-98.

Ng, T. W. H. \& Sorensen, K. L. (2008). Toward A Further Understanding Of The Relationships Between Perceptions Of Support And Work Attitudes: A Meta-Analysis. Group Organization Management, 33, 243-268.

Özdevecioğlu, M. (2013). Algılanan Örgütsel Destek ile Örgütsel Bağlilik Arasindaki İlişkilerin Belirlenmesine Yönelik Bir Araştirma. Dokuz Eylül Üniversitesi İ̈BF Dergisi, 18(2), 113-130.

Öztürk, Y. (2014). The Relationship of Authentic Leadership and Participative Climate With Employee Voice: The Moderating Role of Personality and Organizational Identification. Doktora Tezi, Marmara Üniversitesi, Sosyal Bilimler Enstitüsü, İşletme ABD, İstanbul.

Parasuraman, S., Greenhaus, J. H., \& Granrose, C. S. (1992). Role Stressors, Social Support, and Well-Being Among Two-Career Couples. Journal of Organizational Behavior, 13(4), 339-356. 


\section{Erkubilay - F. K. Şentürk 12/2 (2020) 1820-1833}

Pekdemir, I., Koçoglu, M. \& Güney, Ç. G. (2013). Birey-Örgüt Uyumunun Açıcça Konuşma Davranışı Üzerindeki Etkisinde Algılanan Yönetici Desteğinin Aracılık Rolü: MBA Öğrencilerine Yönelik Bir Araştırma. İşletme İktisadi Enstitüsü Yönetim Dergisi, (75), 83-104.

Premeaux, S. F. \& Bedeian, A. G. (2003). Breaking the silence: The moderating effects of self-monitoring in predicting speaking up in the workplace. Journal of Management Studies, 40(6), 1537-1562.

Rusbult, C. E., Zembrodt, I. M. \& Gunn, L. K. (1982). Exit, voice, loyalty, and neglect: responses to dissatisfaction in romantic involvements. Journal of Personality and Social Psychology, 43(6), 1230-1242.

Rushton, J. P., Chrisjohn, R. D. \& Fekken, G. C. (1981). The Altruistic Personality And Self Report Altruism Scale. Person And Individual Differences, 2(4), 293- 302.

Schaubroeck, J., Cotton, J. L. \& Jennings, K. R. (1989). Antecedents and Consequences of Role Stress: A Covariance Structure Analysis. Journal of Organizational Behavior, 10(1), 35-58.

Semerci, B. A. (2016). Sosyal Destek ve Cinsiyete Yönelik Kalıp Yargıların Stres ve Iş Aile Arasındaki Çatışmalara Etkisi: Kadın ve Erkek Arasındaki Farklliklar. Doktora Tezi, Hacettepe Üniversitesi Sosyal Bilimler Enstitüsü, İşletme Anabilim Dall, Ankara.

Stokes, J. P. \& Levin, I. (1986). Gender Differences in Predicting Loneliness From Social Network Characteristics. Journal of Personality And Social Psychology, 51(5), 1069.

Şentürk, F. K. \& Tekin, Y. (2015). Örgütsel Bağlllık, Örgütsel Destek ve İş Arkadaşı Desteğinin İşgören Performansı Üzerine Etkileri: AVM Çalışanları Örneği. Alanya Isletme Fakültesi Dergisi, 7(2), 195-206.

Tekeş, B. \& Hasta, D. (2015). Özgecilik Ölçeği: Geçerlik ve Güvenirlik Çalışması. Nesne Psikoloji Dergisi, 3(6), 55-75.

Thomas, W. H. NG. \& Feldman, D.C. (2013). A meta-analysis of the relationships of age and tenure with innovation-related behaviour. Journal of Occupational and Organizational Psychology, 86(4), 585-616.

Trommsdorff, G., Friedlmeier, W., \& Mayer, B. (2007). Sympathy, Distress, and Prosocial Behavior of Preschool Children in Four Cultures. International Journal of Behavioral Development, 31(3), $284-293$.

Tuğsal, T. (2017). Çalışanların İş-Yaşam Uyumları ve Tükenmişlikleri Arasındaki İlişkide Sosyal Desteğin Aracılık Etkisi. Akademik Bakış Dergisi, Sayı: 59, 382-399.

Ünver, S. (2016). Explaining service employees' voice behavior: a multilevel, systems theory approach Doctoral Dissertation, İstanbul Bilgi Üniversitesi, Sosyal Bilimler Enstitüsü, İşletme ABD, İstanbul.

Van Dyne L. \& Le Pine, J. A. (1998). Helping and Voice Extra-Role Behavior. Evidence of Construct And Predictive Validity. Academy of Management Journal, 41(1), 108-119.

Van Dyne, L., Ang, S., \& Botero, I. C. (2003). Conceptualizing Employee Silence And Employee Voice As Multidimensional Constructs. Journal of Management Studies, 40(6), 1359-1392.

Walumbwa, F. O., \& Schaubroeck, J. (2009). Leader personality traits and employee voice behavior: mediating roles of ethical leadership and work group psychological safety. Journal of Applied psychology, 94(5), 1275-1286.

Yang, Y., Zhu, R. \& Liu, W. (2010). I warn you because I like you: Voice behavior, employee identifications, and transformational leadership. The Leadership Quarterly, 21(1), 189-202.

Yıldız, S., Taştan Boz, İ. \& Yıldırım, B. F. (2012). Kişilik Tipi İle Olumlu Sosyal Davranış Arasındaki İlişki: Marmara Üniversitesi Öğrencileri Üzerinde Bir Araştırma. Atatürk Üniversitesi İktisadi ve İdari Bilimler Dergisi, 26(1), 215.

Yöntem, M. K. \& İlhan, T. (2013). Benlik Kurguları ve Otantikliğin Özgecilik Üzerindeki Yordayıcı Gücünün İncelenmesi. Turkish Studies, 8(8), 2291-2302.

Zeytinoğlu, I. U., Denton, M. A., Webb, S., \& Lian, J. (2001). Self-Reported Musculoskeletal Disorders Among Visiting And Office Home Care Workers. Women \& Health, 31(2-3), 1-35.

Zhou, J. \& George, J.M. (2001). When Job Dissatisfaction Leads to Creativity: Encouraging the Expression of 
C. Erkubilay - F. K. Şentürk 12/2 (2020) 1820-1833

Voice. Academy of Management Journal, 44(4), 683-96. 